Western University

Scholarship@Western

Management and Organizational Studies

Management and Organizational Studies

Publications

Department

$11-10-2009$

\title{
Worker control as a facilitator in the match between education and jobs
}

Johanna Weststar

Western University, weststar@uwo.ca

Follow this and additional works at: https://ir.lib.uwo.ca/mospub

Part of the Business Administration, Management, and Operations Commons, and the Work, Economy and Organizations Commons

Citation of this paper:

Weststar, Johanna, "Worker control as a facilitator in the match between education and jobs" (2009).

Management and Organizational Studies Publications. 26.

https://ir.lib.uwo.ca/mospub/26 


\title{
Worker CONTROL AS A FACILITATOR IN THE MATCH BETWEen EdUCATION AND JoBS
}

\author{
Running Head: Worker Control in Education and Job Match
}

\author{
Johanna Weststar \\ Sobey School of Business \\ Saint Mary's University \\ weststar@smu.ca
}

A fully edited, peer-reviewed version of this paper was first published in the British Journal of Industrial Relations and should be cited as follows:

Weststar, J. (2009). Worker control as a facilitator in the match between education and jobs. British Journal of Industrial Relations, 47(4), 723-740.

This paper examines the relationship between worker control and subjective underemployment among workers who have more education than is needed for entry into their jobs (credential underemployment). Results indicate that social and technical control are related to a greater sense of education-job matching. Workers who have credential underemployment are less likely to report subjective underemployment (underutilization and lack of fit between education and job) if they have higher levels of workplace control. This article contains implications for job design and the role of employers and managers in fostering the utilization of their workforces.

Word Count: 5315

\section{Acknowledgments:}

Data from the 2003/4 National Survey of Work and Lifelong Learning were provided by the Institute for Social Research, York University. The survey was funded by the Social Sciences and Humanities Research Council of Canada (SSHRC), and was completed for the research network for The Changing Nature of WORK AND LIFELONG LEARNING (WALL) in the New Economy under the direction of Dr David Livingstone, Principal Investigator and Doug Hart, Project Manager from the Ontario Institute for Studies in Education (OISE) at the University of Toronto. These organizations and individuals are not responsible for the analyses and interpretations presented here. I thank Morley 
Gunderson, David Livingstone, Michele Campolieti and two anonymous reviewers for their helpful comments on earlier drafts and Milosh Raykov for technical assistance with the dataset. This research was supported by a SSHRC doctoral fellowship.

\section{Introduction}

“One day will everyone have a university degree and work for the minimum wage?" (OECD, 2007; 11) So wonders Barbara Ischinger, Director of Education for the OECD in her editorial comments to the 2007 Education at a Glance report. Her question was prompted by the findings of the report which outline that the acquisition of both upper secondary and tertiary educational credentials has been rising across OECD countries over the past two decades (OECD, 2007). Despite these reports, or perhaps because of them, the call for more education continues. For example, Canadian government reports state that "countries that succeed in the $21^{\text {st }}$ century will be those whose citizens are creative, adaptable and skilled" and that "the knowledge-based economy means an everincreasing demand for a well-educated and skilled workforce..." (Government of Canada, 2002; 5-7). This report reflect the tone and message of the OECD Education at a Glance report (OECD, 2007), as well as the governmental messages for many other industrialized countries.

The darker side of Ischinger's question - that highly educated individuals will be working for the minimum wage - is not explicitly supported in the OECD report. As least in terms of labour-market value of educational credentials, Ischinger concludes that the "benefits of higher education have not deteriorated as higher education has expanded." (OECD, 2007; 13) However, an economic assessment of the individual 
returns to education is just one component of the total impact that rising education rates have on labour markets, individual workers and their jobs.

If the knowledge economy requires ever more highly educated workers, it must also require the maximal use of the knowledge and abilities that workers have acquired. However, a growing body of research documents the incidence of the underemployment of workers (see for example Berg, 1970; Freeman, 1976; Feldman, 1996; Livingstone, 1999; Sloane, 2002; Wald, 2004). Using two large Canadian datasets, Wald (2004) places underemployment rates at 20-26 percent while other estimates of various facets of underemployment have been growing over the past two decades (Burris, 1983; Livingstone, et al., 2003). Canada and the United States show higher incidence levels compared to other OECD countries, though the concern and subsequent documentation of underemployment in European countries is growing (see Brisbois, 2003; Brynin, 2002; Green, et al., 2002; Groot \& Maassen van den Brink, 2000; Sloane, 2002; Wirz \& Atukeren, 2005).

Underemployment has negative and costly impacts for employees and organizations. For example, various dimensions of underemployment have been positively linked to turnover intentions and job hunting activity (Feldman and Turnley, 1995; Maynard et al., 2006; Wald, 2004b), poor job satisfaction (Jones-Johnson and Johnson, 2000; Khan and Morrow, 1991; Maynard et al, 2006; Maynard and Joseph, 2008), increased 'careerism' (Feldman and Weitz, 1991; Rousseau, 1990) and negatively linked to other job attitudes such as work commitment, job involvement and internal work motivation (Feldman and Turnley, 1995). Aspects of underemployment have also been linked to negative mental 
health outcomes such as depression and low self-esteem (Jones-Johnson and Johnson, 1991). Despite these negative impacts, few studies have explicitly addressed how underemployment can be eliminated or its effects alleviated.

This article examines the role that the structure and design of organizations and jobs plays in reducing feelings of subjective underemployment (definition expanded below). It acknowledges that power imbalances occur in employer-employee negotiations over working conditions, knowledge requirements and knowledge use (Livingstone, 1999) and suggests that the allocation of control in the workplace can impact an employee's ability to navigate their job space and apply their knowledge. The strategic design of jobs within organizations becomes the focus rather than educational reform or individual returns to educational attainment. This framework acknowledges the large reservoirs of knowledge and ability that workers bring to jobs and questions how their use can be maximized to the satisfaction and success of both employers and employees.

The analyses below use the Canadian 2004 Work and Lifelong Learning (WALL) dataset. The dataset is unique and well-suited to this research because it was specifically designed to link underemployment measures with particular labour process variables. As such this research is the first to examine the association between two dimensions of workplace control and two measures of subjective underemployment. The results indicate that both social and technical control are positively associated with decreased incidence of subjective underemployment. This information is of critical importance to organizations competing in the global knowledge economy. The decisions that employers and managers make regarding job design, workplace structure and 
organizational culture are of strategic importance to knowledge utilization, employee input and innovation, and the facilitation of 'learning organizations' that can succeed in the new economy.

The paper is arranged as follows: Section 2 provides definitions and the conceptual framework that links underemployment and workplace control; Section 3 presents the data and methodology; Section 4 contains the empirical results and related discussion; and Section 5 concludes.

\section{Conceptual Framework}

The study of the mismatch of education and jobs is complicated by the use of definitions that stem from a variety of disciplines. 'Over-education' has been used to categorize a surplus of educational credentials over those required for entry into the job or for performance of the job. 'Over-qualification' has been defined similarly, but users purposely adopt this term rather than over-education to avoid the connotation of 'surplus education'. 'Over-skilling' has been used to refer specifically to an underutilization of knowledge or skills. Underemployment has also been used somewhat synonymously with many of these terms. As well, unemployment is often seen as the extreme form of underemployment. Writing from a sociology and education perspective, Livingstone (1999) gathered these definitions under one roof and clarified the important distinctions among them. He defined 6 'faces' of underemployment: the talent use gap, structural unemployment, involuntary reduced employment, the credential gap, the performance gap, and subjective underemployment $(1999 ; 52)$. The credential gap is defined as the 
difference between education attained and education required for entry into the job (overqualification or over-education in other literature). The performance gap is defined as the difference between education attained and the education needed to do the job adequately. Subjective underemployment is workers' sense of whether or not their knowledge and abilities are being adequately utilized in their jobs. In past research, it has been measured in terms of perception of fit between qualifications and jobs, feelings of opportunity to use knowledge and abilities, and sense of entitlement to a better job (Livingstone, 1999; 85).

There are correlations among many of the faces of underemployment. For example, it would make sense that a worker who is underemployed due to a credential gap would report subjective underemployment because they would have underutilized knowledge and abilities. However, this correspondence is not complete. Green and McIntosh (2007) investigated the apparent conundrum of people who are by definition overqualified or have a credential gap (i.e., they have attained a higher level of formal schooling than their job requires for entry), but report adequate utilization of their skills. The authors report that only $47 \%$ of the employees in their sample who have credential underemployment say that they have underutilized skills and abilities (Green and McIntosh, 2007; 432). Green and McIntosh examined two theories as explanations for this lack of correspondence and concluded that some workers are legitimately 'overqualified' and also 'over-skilled'. However, they also found support for an additional explanation: the 'heterogeneous workers' theory. This states that workers within a particular education level have aspects of unobserved human capital and are therefore 
heterogeneous with respect to their actual knowledge and abilities. Therefore some workers who have credential underemployment are actually in jobs that are commensurate with their true knowledge and abilities so they do not report underutilization or subjective underemployment.

This explanation seems plausible, particularly if one considers the range of academic marks that all result in the conferring of a specific degree or diploma. However, the research presented in the current article posits a third explanation for the difference between definitional 'overqualification' rates and reports of knowledge and skill utilization/subjective underemployment. This explanation focuses not on the heterogeneous nature of the employees or credential holders, but on the heterogeneous nature of the jobs themselves and the ability of workers to influence their job tasks through workplace control.

Unlike the terms 'overqualification' or 'overeducation', the term underemployment emphasizes employment rather than education. On the face, overqualification and overeducation imply a problem with the knowledge and abilities that workers have acquired (i.e., they are too high); underemployment implies a problem with the jobs that workers hold. As Burris $(1983 ; 106)$ stated, "underemployment is a structural problem which cannot be explained by blaming individuals... analysts of underemployment should focus more on the workplace and less on 'managing' the system of higher education to bring it into line with the occupational sector." The terminology of underemployment moves us away from human capital theory and educational reform. Instead the focus is placed on the micro-social dimensions of the workplace where workers are variously able 
to apply past learning depending on their ability to interact with and contribute to the changing nature of their jobs. As Pankhurst (2005) argued, the job contract is open and there are a multitude of unobserved, unmeasured and unaccounted for facets of job tasks. Each day employees navigate their job space and engage in problem-solving to deal with expected and unexpected problems. In this environment the written job description, the documented job analysis and the formal educational requirements for jobs are inadequate signals of job requirements.

Burris (1983) highlighted a growing contradiction between the knowledge of workers, increasingly codified by educational credentials, and the requirements of jobs. The workers of the knowledge economy have normalized a greater need for creativity and autonomy through their participation in higher levels of formal schooling and through participation in other less formal forms of learning and development. As Burris noted $(1983 ; 107)$, this 'new working class' is “empowered by a sense of educational qualification" and is increasingly discontented with the nature of workplace control. She provided qualitative evidence that workers with higher education used the autonomous and creative work that they had performed in college as a referent to their boring clerical jobs. As a result, they tended to feel more dissatisfied than their less educated counterparts. However, Burris concluded that the educational background of workers seems less important in perceptions of underemployment than the characteristics of the job. The clerical workers in her sample explicitly and abstractly referenced issues of workplace hierarchy and workplace control when they were describing their perceptions of underemployment. 
It is from this basis that more explicit linkages are drawn between workplace control and subjective underemployment. In their accounts of the triggers of their perceived underemployment, workers in Burris' sample referred to two aspects of workplace control: social and technical ${ }^{1}$. For example, workers discussed the 'nature of workplace control and organization', 'overly stringent or incompetent supervision', 'favoritism', 'lack of autonomy and control', 'lack of opportunity to learn and grow on the job', as well as the 'lack of autonomy or the need for greater task diversity' (Burris, 1983; 100). This relationship between workplace control and underemployment has also been proposed by Livingstone $(1999 ; 226-275)$. Yet, the association has not been tested with quantitative rigor.

In the analyses presented below, it is hypothesized that greater levels of social and technical control will be related to a sense of education-job match as opposed to underemployment on two measures of subjective underemployment (defined in more detail below). Workers who are credentially underemployed have the opportunity through increased control to change the nature of their jobs. Workers with more social control can advocate for alternative tasks, additional projects or expanded roles. Workers with more technical control can dictate their approach to a project, plan the course of a set of tasks and apply whatever tools they deem necessary. In this way workers with more control can change their jobs so that the jobs better match their educational background and they can apply more of their knowledge and abilities on the job. By definition they may hold more formal credentials than the job requires for entry, but in practice they have been able to expand or alter the job to overcome this credential gap. 
As a result they report less subjective underemployment, which is a more global measure.

\section{Data and Methodology}

The dataset from the Work and Lifelong Learning (WALL) project ${ }^{2}$ was used for the analyses. The WALL telephone survey was conducted in 2004 with a large representative sample of the adult $(18+)$ Canadian population $(\mathrm{N}=9,063)$. It is uniquely suited for this study in that it provides unprecedented quantitative detail on measures of underemployment and the labour process. Also, it provides a large heterogeneous sample of workers across industries and with varied educational backgrounds so findings can be applied to the general population. Some studies of underemployment or overqualification focus on graduates of higher education as it has been proposed that these populations are more at risk of underemployment. The analyses presented here include workers across industries and occupations because there is reason to assume that workers in ostensibly 'low skill' jobs would also be able to apply more of their knowledge and abilities if given more input into their jobs. As outlined by Livingstone and Sawchuk (2005) much of the knowledge base of working people is hidden and assumed absent because of constraining social and technical production processes. That said the sample is limited in that only workers who have credential underemployment (more education than is needed for entry into their jobs) are included in the analysis. This effectively excludes workers with very low levels of education. The final subsample used to estimate the models included 1,438 persons ${ }^{3}$. 
Two dependent variables of self-reported ${ }^{4}$ subjective underemployment were used in two separate analyses. The first is a measure of the subjective gap (Livingstone, 1999; 85-89) which is the respondent's perception of the match between their schooling and their current job: "In terms of your formal education do you feel you are overqualified, adequately qualified, or underqualified ${ }^{5 \%}$. This dependent variable has three levels and a multinomial logit regression was estimated using adequately employed or 'matched' as the reference group. In the second analysis education-job relation is also a perception of fit variable that measures the degree of relationship between the respondents' schooling and their job (Livingstone, 1999; 85; see also Maynard et al. 2006; 519). It has three categories and a multinomial logit regression ${ }^{6}$ was used with 'closely related' as the reference category.

The social control and technical control measures consist of two items each. Social control includes participation in policy-level decision-making as well as an occupational class variable. In this class variable respondents are coded as either: manager, supervisor, professional, service worker, or industrial worker (see Livingstone and Scholtz, 2006; 76-77). The inclusion of occupational class as a measure of social control recognizes the relationships between control and educational attainment, job status, and position within the occupational hierarchy. This acknowledges the general pattern that different occupational groups or occupational settings have different capacities for workplace control. Managers were coded to have the highest social control with industrial workers having the lowest. Technical control includes the ability to plan some aspects of your own work and choice in the way you do your job. Each scale ranges 
from 2-10, where lower values denote lower social and lower technical control. The Cronbach alpha scores were 0.58 for social control and 0.61 for technical control.

Each analysis also included variables to account for individual factors that have been shown or been hypothesized to affect underemployment. First, educational dummies were included because research indicates that the number of underemployed university graduates has grown in the last decade (Kelly et al., 1997; Li et al., 2006) and university graduates may be at particular risk of underemployment (Frenette, 2004; Li et al., 2006). Respondents with secondary school diplomas were used as a reference group because no respondents with elementary level schooling registered as having credential underemployment.

Dummy variables denoting the time period of immigration (with Canadian born as the reference category) were also included to potentially corroborate the burgeoning research that suggests immigrants are more at risk of underemployment due to inadequate recognition of their foreign schooling or work experience (Aydemir \& Skuterud, 2005; Banerjee, 2007; Frenette \& Morissette, 2003; Green \& Worswick, 2002; Li et al., 2006; 8-9).

Age and tenure variables were also included (each scaled into ten year brackets). Studies have indicated that among workers with university degrees, younger workers were more likely to feel 'overqualified' than older workers (Kelly et al., 1997; Li et al., 2006). These findings tie in with Pankhurst \& Livingstone's (2006) theoretical argument that workers and jobs come together over time. That is, there is a constantly renegotiated relationship between workers and their jobs such that, over time, workers will shape their 
jobs (or move into new jobs) to better fit their knowledge and abilities. For older workers, the timeline for that shaping is shorter, and perhaps the desire to change jobs or job situations or the ability to do so is lessened. However, older workers may be more likely to remain in situations of 'overqualification' than younger workers (Li et al., 2006; 7-8). This may reflect a compositional effect in that older workers who have remained in a job mismatch are likely to be problematic individuals. As evidenced by the fact that they have not yet found a match, eventual matches may be unlikely. These arguments can be extended more completely to workers who have longer tenure in their jobs as they will have had more opportunity to influence and be influenced by changing job requirements. However, for those with long tenure who have remained in a state of mismatch, eventual matches may also be less likely.

Union status was included to capture the notion that unionized workplaces have more structured hiring criteria and job descriptions. This standardization could lead to a closer match between the applicants hired and the jobs they perform (Li et al., 2006; 14); however, such explicit structure could also lead to jobs that are too narrow to fully incorporate the wealth of a worker's knowledge and ability.

A group of variables was also included to express other faces of underemployment that could influence perceptions of subjective underemployment: structural unemployment and involuntary reduced employment (Livingstone, 1999; 63-70; Maynard et al., 2006; 512). Included are a dichotomous variable representing whether the respondent is a temporary worker, a dichotomous variable representing whether the respondent has been unemployed in the last five years, a continuous count variable of the 
number of jobs the respondent has held in the last five years, and a continuous variable of the number of hours the respondent works per week (scaled into ten hour brackets). Taken together these variables test for the notion that more continuous and stable work provides greater opportunity for workers to negotiate their job space and match the entire range of their knowledge and abilities to their jobs. Li et al. $(2006 ; 12)$ reported that 42 percent of part-time workers in Canada experienced underemployment and that this was significantly higher than their full-time counterparts. Similar to their findings with older workers, however, full-time workers who were in situations of underemployment were more likely to stay there. This finding suggests that time or permanency on the job may not be enough to encourage more education-job matching if the characteristics of the job or workplace do not allow sufficient reciprocity between the worker and the job. Crosssectional data does not allow for discussions of causality and time-based interferences are limited; however, the suggested association between job stability and underemployment that is raised with this data pinpoints an area that can be revisited with additional research.

The remaining independent variables are controls that are commonly used in this literature: sex, visible minority status, region and industry.

\section{Results and Discussion}

The descriptive statistics for all variables are included in Table 1. Similar to the sample used by Green and McIntosh (2007), only 40 percent of workers with credential underemployment report a subjective gap and only 44 percent state that their education is 
not at all related to their jobs. Tables 2 and 3 present marginal effects rather than the multinomial logit coefficient estimates for the association between subjective underemployment and workplace control. The regression presented in Table 2 uses 'adequately employed' as the reference group is the middle ground between underemployment and underqualification. In the regression presented in Table 3 the reference group is at one end of the spectrum. Here the reference is that formal education is closely related to the job with the options for deviation being education that is somewhat related to the job and education that is not at all related to the jobs.

\subsection{Social and Technical Control}

For the subjective gap measure (Table 2), both social and technical control have a negative relationship with underemployment as opposed to the reference group of adequately employed. Each one unit increase of social control (scale of 2-10) is associated with a decreased probability of underemployment of just over two percentage points. Taken at the standard deviation of social control this increases to just under five percent $(2.2 * 2.028)$. Each one unit increase of technical control is associated with a decreased probability of underemployment of approximately three percentage points. At the standard deviation of technical control this increases to just over six percent $(2.9 * 2.105)$. Neither social nor technical control has a statistically significant association with feeling 'underqualified' as opposed to adequately employed. As the sample is restricted to people who have credential underemployment, only three percent of the sample report subjective underqualification, so a non-significant result is not surprising. 
The results for the education-job relation measure corroborate the association between both social and technical control and the subjective gap measure. Referring to Table 3, respondents with higher levels of social control and respondents with higher levels of technical control have a greater probability of saying their education is closely related to their job than not at all related (2.9 and 2.1 percentage points, respectively).

\subsection{Other Independent Variables}

The other independent variables were included primarily as control variables, however past literature did prompt some hypotheses about groups that may be more at risk of underemployment. However, the results for visible minorities, immigrants and potentially more contingent workers (those with unemployment spells, temporary workers, part-time workers, and those with a high number of jobs in the past five years) are not overwhelming. The lack of statistical significance for some associations may be largely due to the restrictions on the sample. Only respondents who are credentially underemployed were included. An examination of the data frequencies shows that only a small percentage of these 'at risk' workers experiences credential underemployment (i.e., less than $15 \%$ for each case). Some associations do exist, however. Workers who work more hours are less likely to report no education-job relation than a close relation - three percentage points for each 10 hour bracket. As well, workers who have held multiple jobs in the past five years are more likely to report underemployment than matching on the subjective gap variable. These findings have implications for the trends toward parttime work and reduced job security. 
This issue of job security is picked up in the tenure variable as well. Workers with more tenure are less likely to report underemployment than matching on the subjective gap variable. They also report more correspondence between their education and their jobs. The closer connection for more tenured workers supports the idea that workers' endogenous learning on the job is pivotal in closing gaps and/or making new connections between formal schooling and job requirements. The job tenure has a small, but significant correlation with social control and this may be implicit in these results. Workers with more tenure typically gain more responsibility and authority and would be better able to dictate and shape their work.

Workers who have credential underemployment and hold a post-secondary degree or diploma are more likely to report that their education is closely related to their jobs. This may be the result of some justification of their educational efforts. It is also likely that jobs requiring higher education are in a more specifically defined field. However, respondents with university degrees are approximately 20 percentage points more likely to report underemployment on the subjective gap variable than those with secondary education. This means that workers with university degrees who are in jobs that require less than their credential more readily translate this mismatch into subjective feelings of underemployment than workers with less education. This result is of particular importance given the trends towards increasing enrollments in post-secondary schooling, especially at the university level. These data can be taken as evidence that many jobs are not keeping pace with the increasing knowledge and ability reservoirs, or the workplace expectations of university graduates. 


\section{Conclusions and Implications}

Across industrialized countries participation in higher education has grown considerably in the last four decades. Three-quarters of the respondents in the WALL survey used by this study feel that post-secondary schooling is needed to get along in society (Livingstone \& Scholtz, 2006; 39). Government departments are producing reports stating that we must invest in workplace learning to be competitive in the global economy, and employers call for more skill upgrading. The credentials needed to enter jobs have increased, as have on-the-job learning time, and computer use across all sectors of the economy. Yet, according to the WALL survey, a portion of the labour force reports educational attainments beyond what is needed for entry into their jobs. To further complicate matters, among these credentially underemployed, only about half report subjective feelings of underemployment.

Other research has shown that some of these workers are not truly underutilized, but that they have lower knowledge and ability levels than their degree/diploma signals (Green and McIntosh, 2007). The analyses presented here add an additional explanation that focuses on the workplace rather than the individual. This research used the unique Work and Lifelong Learning (WALL) survey to examine whether worker control can reduce feelings of subjective underemployment among the credentially underemployed. That is, do workers with more job control find a way to overcome their credential underemployment such that they feel adequately employed and utilized? This idea has been theoretically presented (Livingstone, 1999) and reinforced using qualitative data (Burris, 1983), however, quantitatively rigorous tests have been lacking. The results 
indicate that workers who enjoy more social and technical control -- those who have more social authority and participate more in policy-level decision making, and/or those who have more autonomy and task discretion in their daily jobs - are less likely to report subjective underemployment as defined in terms of perception of fit between education and job.

This research is important for organizations and policy-makers world-wide because it helps to shift the focus from a preoccupation with educational reform and the choices that individuals make regarding their educational participation, to the impact of workplace and job design. Calls from policy makers for workers to universally increase their levels of formal schooling and further adult education will perpetuate the current problem of underemployment and job mismatch. Governmental messages about education-industry correspondence must also shift. Educational systems should not be called upon to produce specific workers for specific industries, but to encourage the development of core capabilities and workers with the ability to learn and adapt so that they can meet the changing demands of their future jobs. It is the workplaces and jobs themselves that should be reformed to better match the workforce. Governments, employers and managers would do better to focus on workplaces and jobs and create policies that assist rather than constrain workers as they manage the shifting balance between learning and working.

Ultimately, then, the onus of responsibility for creating high functioning learningoriented workplaces is on employers and managers. They can play an important strategic role in the utilization of their workforces through modifications to their workplace 
structure, culture and job design. Social and technical aspects of worker control can be increased through information sharing, delegation of real power and decision-making authority, solicitation and use of employee input and encouraged autonomy and discretion in task completion (see Green, 2008 for a recent account of determinants of task discretion). This increased control acknowledges that workers have the greatest understanding about the changing demands of their jobs and are most often the best people to decide how to apply their reservoirs of knowledge and abilities to get the job done. Such a system would be able to account for many of the inefficiencies of the labour market as well as the imprecise signaling capacity of educational credentials by allowing workers to address and rectify their credential mismatch.

Some direct actions could be to improve the human resources function of job analysis, recruitment and selection, and performance management to improve the correspondence between entry requirements for a job and the actual requirements of the job itself. Movement to more skills-based job assessment as opposed to job-based assessments would also aid this process. Implicit in these recommendations is more worker input into job entry requirements (from current incumbents of a job) as well as worker input into their performance expectations and development needs. In addition, employers and managers could increase worker input into project timelines and deadlines and conduct debriefing sessions of completed projects with an intention to change and improve based on worker experiences. They could also increase the flexibility for workers to move seamlessly between working and learning tasks to maximize productive 
work time, and increase worker input into the allocation of job tasks among coworkers or team members.

Though it is easier to see how worker control could be increased in those jobs where it is already present (i.e., managerial, supervisory, and professional occupations), the recommendations made above apply across occupations and occupational hierarchies. Service and industrial work has been rationalized and 'deskilled', but that does not mean this course cannot be changed. Some successful examples of worker input in industrial settings include joint occupational health and safety committees and some quality management programs. Initiatives such as co-operatives and worker ownership, as well as the economic democracy advocated by Livingstone $(1999 ; 240-275)$ are more dramatic examples of increased worker control that could occur across the occupational spectrum.

A limitation of this research is that the dataset is cross-sectional. This limits discussions of causality and the direction of the relationship between control and underemployment. However, some qualitative research is emerging that supports the suggestion made in this paper that control leads to increased matching (see Weststar, in press). A second limitation is the use of two measures of subjective underemployment that are still closely tied to formal schooling. As such this study largely follows traditional understandings about how workers acquire knowledge and abilities. Additional studies are needed to capture the potential underemployment that could emerge through the (under)utilization of the knowledge and abilities acquired through informal learning activities. Literature documenting the role of informal learning in 
moderating feelings of education-job mismatch is growing, however additional research in needed (for example see CLC, 2002; Colardyn \& Bjornavold, 2004; HRDC, 1995; Norwegian Ministry of Education and Research, 2003; Skule, 2004 for work on prior learning assessment and recognition or validation of informal learning; and Weststar, in press, for the role of informal learning in maintaining competency). The documentation and impact of these activities is vital to our understanding of lifelong learning and our competitiveness in the knowledge economy. In a similar vein, research that draws greater links between the knowledge and abilities acquired through unpaid activities such as housework, volunteer work and hobbies will aid in the move from narrow consideration of formal credentials and capture the full spectrum of knowledge and abilities that workers bring to their jobs. This research is necessary to expose the seamlessness of 'life' and 'work' learning spheres such that a more complete learning and ability utilization model can be brought to bear in workers jobs. 
Table 1:

Descriptive Statistics (omitted reference in square brackets)

\begin{tabular}{|c|c|c|c|}
\hline Variable Name & Mean & $\begin{array}{l}\text { Standard } \\
\text { Deviation }\end{array}$ & Range \\
\hline Subjective Gap & .831 & .914 & $0-2$ \\
\hline Education-Job Relationship & .860 & .804 & $0-2$ \\
\hline Social Control & 4.602 & 2.028 & $2-10$ \\
\hline Technical Control & 6.893 & 2.105 & $2-10$ \\
\hline Female & .469 & .472 & $0-1$ \\
\hline Visible Minority & .158 & .346 & $0-1$ \\
\hline \multicolumn{4}{|l|}{ Immigration Year } \\
\hline [Canadian Born] & .805 & .391 & $0-1$ \\
\hline Pre-1990 & .114 & .301 & $0-1$ \\
\hline Post-1990 & .081 & .257 & $0-1$ \\
\hline Age (10 year brackets) & 2.667 & 1.167 & $1-7$ \\
\hline Tenure (10 year brackets) & 1.338 & .678 & $1-5$ \\
\hline $\begin{array}{l}\text { Work Hours (10 hour } \\
\text { brackets) }\end{array}$ & 4.610 & 1.216 & $1-10$ \\
\hline Temporary Worker & .156 & .343 & $0-1$ \\
\hline Number of Jobs (in last $5 \mathrm{yrs}$ ) & 2.538 & 2.176 & $0-30$ \\
\hline Unemployed (in last 5 yrs) & .151 & .339 & $0-1$ \\
\hline Unionized & .301 & .434 & $0-1$ \\
\hline \multicolumn{4}{|l|}{ Region } \\
\hline [Ontario] & .380 & .484 & $0-1$ \\
\hline Atlantic & .078 & .254 & $0-1$ \\
\hline Quebec & .260 & .415 & $0-1$ \\
\hline Western & .282 & .426 & $0-1$ \\
\hline \multicolumn{4}{|l|}{ Industry } \\
\hline [Manufacturing] & .321 & .403 & $0-1$ \\
\hline Primary & .167 & .353 & $0-1$ \\
\hline Business Services & .117 & .304 & $0-1$ \\
\hline Distributive Services & .174 & .359 & $0-1$ \\
\hline Consumer Services & .089 & .270 & $0-1$ \\
\hline Public Services & .132 & .320 & $0-1$ \\
\hline \multicolumn{4}{|l|}{ Schooling } \\
\hline [Secondary] & .242 & .435 & $0-1$ \\
\hline College & .496 & .473 & $0-1$ \\
\hline University & .262 & .416 & $0-1$ \\
\hline
\end{tabular}


Table 2:

Marginal Effects from Multinomial Logit Estimates of Subjective Gap (perception of fit between schooling and job requirements)

\section{Marginal Effects}

[Reference Group: Adequately Employed]

\begin{tabular}{|c|c|c|c|c|}
\hline \multirow{2}{*}{$\begin{array}{l}\text { Variable Name } \\
\text { Social Control (2-10) }\end{array}$} & \multicolumn{2}{|c|}{ Underemployed } & \multicolumn{2}{|c|}{ Underqualified } \\
\hline & $-.022^{* *}$ & $(.009)$ & -.001 & $(.002)$ \\
\hline Technical Control (2-10) & $-.029^{* * *}$ & $(.008)$ & .003 & $(.002)$ \\
\hline Female & -.050 & $(.038)$ & $-.017^{*}$ & $(.010)$ \\
\hline Visible Minority & -.039 & $(.062)$ & .002 & $(.011)$ \\
\hline \multicolumn{5}{|l|}{ Immigrant [Cdn. Born] } \\
\hline Pre-1990 & -.048 & $(.062)$ & $-.022^{* * *}$ & $(.008)$ \\
\hline Post-1990 & .062 & $(.097)$ & .040 & $(.025)$ \\
\hline Age (10 years) & -.018 & $(.016)$ & .001 & $(.005)$ \\
\hline Tenure (10 years) & $-.083^{* * *}$ & $(.029)$ &. .005 & $(.005)$ \\
\hline Hours Worked (10 hours) & -.005 & $(.014)$ & -.003 & $(.002)$ \\
\hline Temporary Worker & .061 & $(.051)$ & -.007 & $(.009)$ \\
\hline No. of jobs in last 5 years & $.023^{* *}$ & $(.009)$ & -.003 & $(.005)$ \\
\hline Unemployed in last 5 years & -.040 & $(.050)$ & .020 & $(.016)$ \\
\hline Unionized & .036 & $(.044)$ & $-.025^{* * *}$ & $(.009)$ \\
\hline \multicolumn{5}{|l|}{ Region [Ontario] } \\
\hline Atlantic & $-.151^{* * *}$ & $(.049)$ & -.010 & $(.009)$ \\
\hline Quebec & $-.145^{* * *}$ & $(.044)$ & .003 & $(.010)$ \\
\hline Western & -.052 & $(.042)$ & -.007 & $(.088)$ \\
\hline \multicolumn{5}{|l|}{ Industry [Manufacturing] } \\
\hline Primary & .025 & $(.055)$ & .008 & $(.016)$ \\
\hline Business Services & -.080 & $(.063)$ & .010 & $(.018)$ \\
\hline Distributive Services & .001 & $(.049)$ & $.046^{*}$ & $(.025)$ \\
\hline Consumer Services & .087 & $(.070)$ & -.011 & $(.012)$ \\
\hline Public Services & $-.132^{* *}$ & $(.053)$ & .063 & $(.042)$ \\
\hline \multicolumn{5}{|l|}{ Schooling [Secondary] } \\
\hline College & -.037 & .043 & -.003 & $(.010)$ \\
\hline University & $.214^{* * *}$ & .047 & -.006 & $(.010)$ \\
\hline$\chi^{2}$ & $\begin{array}{c}168.24 \\
p<.0001\end{array}$ & & & \\
\hline
\end{tabular}

Notes. Standard errors in parentheses. Excluded reference group in square brackets.

Statistical significance denoted by * at the .10 level; ** at the .05 level; *** at the .01 level. 
Table 3:

Marginal Effects from Multinomial Logit Estimates of Education - Job Relation

\section{Marginal Effects}

[Reference Group: Education Closely Related to Job]

Variable Name

\begin{tabular}{|c|c|c|c|c|}
\hline & \multicolumn{2}{|c|}{ to Job } & \multicolumn{2}{|c|}{ to Job } \\
\hline Social Control & $.014^{*}$ & $(.008)$ & $-.029^{* * * *}$ & $(.009)$ \\
\hline Technical Control & -.008 & $(.008)$ & $-.021^{* *}$ & $(.009)$ \\
\hline Female & .017 & $(.077)$ & .001 & $(.039)$ \\
\hline Visible Minority & .084 & $(.124)$ & $-.149^{* * *}$ & $(.056)$ \\
\hline \multicolumn{5}{|l|}{ Immigrant [Cdn. Born] } \\
\hline Pre-1990 & -.028 & $(.120)$ & .047 & $(.068)$ \\
\hline Post-1990 & $-.093^{*}$ & $(.172)$ & .029 & $(.089)$ \\
\hline Age ( 10 years $)$ & $.040^{* * *}$ & $(.018)$ & .013 & $(.018)$ \\
\hline Tenure ( 10 years) & -.025 & $(.024)$ & $-.050^{*}$ & $(.030)$ \\
\hline Hours Worked (10 hours) & .008 & $(.014)$ & $-.030^{* *}$ & $(.014)$ \\
\hline Temporary Worker & .053 & $(.102)$ & .005 & $(.051)$ \\
\hline No. of jobs in last 5 years & $.013^{* *}$ & $(.020)$ & .008 & $(.010)$ \\
\hline Unemployed in last 5 years & -.041 & $(.118)$ & .037 & $(.055)$ \\
\hline Unionized & -.027 & $(.088)$ & .023 & $(.045)$ \\
\hline \multicolumn{5}{|l|}{ Region [Ontario] } \\
\hline Atlantic & .013 & $(.149)$ & .021 & $(.063)$ \\
\hline Quebec & $.132^{* * *}$ & $(.094)$ & $-.180^{* * *}$ & $(.045)$ \\
\hline Western & -.013 & $(.088)$ & $-.132^{* * *}$ & $(.042)$ \\
\hline \multicolumn{5}{|l|}{ Industry [Manufacturing] } \\
\hline Primary & -.015 & $(.133)$ & $.133^{* *}$ & $(.056)$ \\
\hline Business Services & -.040 & $(.153)$ & .017 & $(.061)$ \\
\hline Distributive Services & -.033 & $(.138)$ & .072 & $(.053)$ \\
\hline Consumer Services & $-.151^{* * *}$ & $(.101)$ & $.240^{* * *}$ & $(.068)$ \\
\hline Public Services & -.050 & $(.113)$ & $-.175^{* * *}$ & $(.058)$ \\
\hline \multicolumn{5}{|l|}{ School [Secondary] } \\
\hline College & .046 & $(.094)$ & $-.276^{* * *}$ & $(.043)$ \\
\hline University & .008 & $(.106)$ & $-.272^{* * *}$ & $(.041)$ \\
\hline$\chi^{2}$ & $\begin{array}{l}2.68 \\
0001\end{array}$ & & & \\
\hline
\end{tabular}

Notes. Standard errors in parentheses. Excluded reference group in square brackets.

Statistical significance denoted by * at the .10 level; ** at the .05 level; *** at the .01 level. 


\section{REFERENCES}

Aydemir, A. and Skuterud, M. (2005). Explaining the deteriorating entry earnings of Canada's immigration cohorts: 1966-2000. Canadian Journal of Economics, 38: $641-71$.

Banerjee, R. (2007). An examination of the factors affecting perception of workplace discrimination. Unpublished doctoral dissertation. Toronto, ON: University of Toronto.

Berg, I. (1970). Education and Jobs: The Great Training Robbery. New York: Praeger.

Brisbois, R. (2003). How Canada stacks up: The quality of work - an international perspective. Ottawa: Canadian Policy Research Networks.

Brynin, M. (2002). Overqualification in employment. Work, Employment and Society, 16: $637-54$.

Burris, B. H. (1983). The human effects of underemployment. Social Problems, 31: 96110.

CLC. (2002). Prior Learning Assessment and Recognition (PLAR): A statement of labour values. Ottawa: Canadian Labour Congress. http://canadianlabour.ca/updir/ labourvaluesEn.pdf (accessed April 25, 2007).

Colardyn, D. and Bjornavold, J. (2004). Validation of formal, non-formal and informal learning: Policy and practices in EU Member States. European Journal of Education, 39: 69-89.

Crompton, S. (2002). I still feel overqualified for my job. Canadian Social Trends, Winter: 23-26. Ottawa: Statistics Canada, catalogue no. 11-008.

Feldman, D. (1996). The nature, antecedents and consequences of underemployment. Journal of Management, 22: 385-407.

Feldman, D. C. and Turnley, W. H. (1995). Underemployment among recent business college graduates. Journal of Organizational Behaviour, 16: 691-706.

Feldman, D. C. and Weitz, B. A. (1991). From the invisible hand to the gladhand: Understanding the nature of a careerist orientation to work. Human Resource Management, 30: 237-257.

Freeman, R. (1976). The Overeducated American. New York: Academic Press.

Frenette, M. (2004). The overqualified Canadian graduate: The role of the academic program in the incidence, persistence, and economic returns to overqualification. Economics of Education Review, 23: 29-45 
Frenette, M. and Morissette, R. (2003). Will they ever converge? Earnings of immigrant and Canadian-born workers over the last two decades. Analytical Studies Branch Research Paper 215. Ottawa: Statistics Canada.

Government of Canada. (2002). Knowledge matters: Skills and learning for Canadians. Canada's Innovation Strategy. http://www11.sdc.gc.ca/sl-ca/doc/summary.shtml (accessed October 4, 2006)

Green, D. and Worswick, C. (2002). Earnings of immigrant men in Canada: The roles of labour market entry effects and returns to foreign experience. Ottawa: Citizenship and Immigration Canada, Strategic Research and Statistics.

Green, F. (2008). Leeway for the loyal: A model of employee discretion. British Journal of Industrial Relations, 46: 1-32.

Green, F. and McIntosh, S. (2007). Is there a genuine under-utilization of skills amongst the over-qualified? Applied Economics, 39: 427-439.

Green, F., McIntosh, S. and Vignoles, A. (2002). The utilization of education and skills: Evidence from Britain. The Manchester School, 70: 792-811.

Groot, W. and Maassen van den Brink, H. (2000). Overeducation in the labor market: A meta-analysis. Economics of Education Review, 19: 149-58.

HRDC. (1995). Prior Learning and Assessment Newsletter, 1. Ottawa: Human Resource Development Canada.

Jones-Johnson, G. and Johnson, W. R. (1991). Subjective underemployment and psychological stress: The role of perceived social and supervisor support. Journal of Social Psychology, 132: 11-21.

Jones-Johnson, G. and Johnson, W. R. (2000). Perceived overqualification and dimensions of job satisfaction: A longitudinal analysis. The Journal of Psychology, 134: 537-555.

Kelly, K., Howatson-Leo, L. and Clark, W. (1997). "I feel overqualified for my job..." Canadian Social Trends, Winter. Ottawa: Statistics Canada, catalogue no. 11-008XPE.

Khan, L. J. and Morrow, P. C. (1991). Objective and subjective underemployment relationships to job satisfaction. Journal of Business Research, 22: 211-218.

Li, C., Gervais, G. and Duval, A. (2006). The dynamics of overqualification: Canada's underemployed university graduates. Ottawa: Statistics Canada. Analysis in Brief Series, catalogue no. 11-621-MIE2006039.

Livingstone, D. W. (1999). The Education-Jobs Gap: Underemployment or Economic Democracy. Toronto: Garamond Press. 
Livingstone, D. W., Hart, D. and Davie, L. E. (2003). Public attitudes toward education in Ontario: The $14^{\text {th }}$ OISE/UT survey. Toronto: Ontario Institute for Studies in Education of the University of Toronto.

Livingstone, D. W., and Scholtz, A. (2006). Work and lifelong learning in Canada: Basic findings of the 2004 WALL survey. Toronto: Ontario Institute for Studies in Education of the University of Toronto. http://www.wallnetwork.ca/resources/ WALLSurveyReportFINALMarch2007.pdf (accessed April, 2007).

Livingstone, D. W., and Sawchuk, P. H. (2003). Hidden Knowledge: Organized Labor in the Information Age. New York: Rowman \& Littlefield.

Maynard, D. C., Joseph, T. A. and Maynard, A. M. (2006). Underemployment, job attitudes and turnover intentions. Journal of Organizational Behaviour, 27: 509-36.

Maynard, D. C. and Joseph, T. A. (2008). Are all part-time faculty underemployed? The influence of faculty status preference on satisfaction and commitment. Higher Education, 55: 139-154.

McNamee, S. J. and Vanneman, R. (1983). The perception of class: Social and technical relations of production. Work and Occupations, 10: 437-69.

Norwegian Ministry of Education and Research. (2003). The Competence Reform. Oslo, Norway: Norwegian Ministry of Education and Research, publication no. F-4167 E.

OECD. (2007). Education at a glance 2007: OECD indicators. Paris: Organization for Economic Co-operation and Development (OECD) Publishing.

Pankhurst, K. V. (2005). Education and employment: Overview of research and policy issues. In: T. Wallace, N. Murphy, G. Lepine, and D. Brown (eds.), Exploring New Directions in Essential Skills Research. Ottawa: Public Policy Forum.

Pankhurst, K. V. and Livingstone, D. W. (2006). The labour process: Individual learning, work and productivity. Studies in Continuing Education, 28: 1-16.

Rousseau, D. M. (1990). New hire perceptions of their own and their employer's obligations: A study of psychological contracts. Journal of Organizational Behavior, 11: 389-400.

Skule, S. (2004). Lifelong learning - Norwegian experiences: The role of social partners in developing and implementing lifelong learning policies. Fafo Institute for Labour and Social Research. http://www.fafo.no/indexenglish.htm (accessed April 25, 2007).

Sloane, P. (2002). Much ado about nothing? What does the over-education literature really tell us? International Conference on Over-education in Europe: What Do We 
Know? Berlin, November 22-23. http://www.mpib-berlin.mpg.de/de/aktuelles/ papers/sloane.pdf (accessed April, 2007).

van der Velden, R. and van Smoorenburg, M. (1997). The measurement of overeducation and undereducation: Self-report vs. job-analyst method. Maastricht Research Centre for Education and the Labour Market, ROA-RM-1997/2E.

WALL. no date. Work and Lifelong Learning project website. www.wallnetwork.ca

Wald, S. (2004). The overqualification of Canadian workers. Unpublished doctoral dissertation. Toronto: Centre for Industrial Relations and Human Resources, University of Toronto.

Wald, S. (2004). The impact of overqualification on job search. International Journal of Manpower, 26: 140-156.

Weststar, J. (2007). Give me the room to learn: Associations between workplace control and work-related learning. Just Labour: A Canadian Journal of Work and Society, 11.

Weststar, J. (in press, 2009). Staying Current in Computer Programming: The Importance of Informal Learning and Task Discretion in Maintaining Job Competence. In D. Livingstone (ed.), Education and Jobs: Exploring the Gaps. Peterborough, ON: Broadview Press.

Wirz, A. and Atukeren, E. (2005). An analysis of perceived overqualification in the Swiss labor market. Economics Bulletin, 9: 1-10. 


\section{ENDNOTES}

${ }^{1}$ Based on the arguments of McNamee and Vanneman (1983), social control is defined as control over people and the larger work system and encompasses ownership, authority and managerial roles. Technical control is the control over the micro-level of tools and tasks and includes the discretion workers have to shape and perform their daily work.

${ }^{2}$ Data from the 2003/4 National Survey of Work and Lifelong Learning were provided by the Institute for Social Research, York University. The survey was funded by the Social Sciences and Humanities Research Council of Canada (SSHRC), and was completed for the research network for The Changing Nature of Work and Lifelong Learning (WALL) in the New Economy under the direction of Dr David Livingstone, Principal Investigator and Doug Hart, Project Manager from the Ontario Institute for Studies in Education (OISE) at the University of Toronto. Information on this project is available at www.wallnetwork.ca

${ }^{3}$ Mean substitution was conducted on the small number of item non-response missing values in the explanatory variables (i.e., the largest percent of missing values on a given variable was 3.7 )

${ }^{4}$ Self-reports of underemployment have been criticized on the basis of subjectivity. However, some research has suggested that some more objective measures such as the job analyst approach overestimates measures of overeducation and overqualification relative to the self-report approaches (van der Velden \& van Smoorenburg, 1997). Also, the so called subjective measures may be more appropriate than the objective measures because they can better capture job heterogeneity, skills erosion, and job change (Green et al., 2002; 796; Wald, 2004). As such the self-assessed perception variable (Subjective Gap) and the selfassessed comparison variable (Education-Job Relation) are most suitable for this research for several reasons. Firstly, they are job and individual specific rather than aggregate measures. Secondly, they are not dependent on potentially biased or outdated job classification systems (Green et al., 2002; 796; Pankhurst, 2005). Lastly, these approaches acknowledge that workers are at the core of information about their jobs and that workers' perceptions about their education-job match are relevant whether these perceptions are 'by definition' accurate or illusory (Maynard et al., 2006; 518). It is workers' perception of their work and working environment that dictates their behaviour and, given that many of the outcomes of underemployment are psychologically and materially negative, these perceptions should not be discounted.

${ }^{5}$ This is the terminology used in the WALL survey and does not refer to the academic definition of the credential gap outlined earlier in the paper. The creators of the WALL survey deemed this colloquial definition to be the most understandable to survey respondents. Any questions by the respondents would have been clarified to reflect this. 